\title{
High Dose of FGF-2 Induced Growth Retardation via ERK1/2 De-phosphorylation in Bone Marrow-derived Mesenchymal Stem Cells
}

\author{
Kwang Yong Shim ${ }^{1}$, Fatema Tuj Saima ${ }^{2}$ and Young Woo Eom $^{2, \uparrow}$ \\ ${ }^{I}$ Department of Hematology-Oncology, Wonju College of Medicine, Yonsei University, \\ Wonju, Gangwon-do 26426, Korea \\ ${ }^{2}$ Cell Therapy and Tissue Engineering Center, Wonju College of Medicine, Yonsei University, \\ Wonju, Gangwon-do 26426, Korea
}

\begin{abstract}
Fibroblast growth factor (FGF)-2 is one of the most effective growth factors to increase the growth rate of mesenchymal stem cells (MSCs). Previously, we reported that low dose of FGF-2 (1 ng/ml) induced proliferation of bone marrowderived mesenchymal stem cells (BMSCs) through AKT and ERK activation resulting in reduction of autophagy and senescence, but not at a high dose. In this study, we investigated the effects of high dose FGF-2 (10 ng/ml) on proliferation, autophagy and senescence of BMSCs for long term cultures (i.e., 2 months). FGF-2 increased the growth rate of BMSCs in a dose dependent manner for a short term (3 days), while during long term cultures ( 2 months), population doubling time was increased and accumulated cell number was lower than control in BMSCs when cultured with $10 \mathrm{ng} / \mathrm{ml}$ of FGF-2. $10 \mathrm{ng} / \mathrm{ml}$ of FGF-2 induced immediate de-phosphorylation of ERK1/2, expression of LC3-II, and increase of senescence associated $\beta$-galactosidase (SA- $\beta$-Gal, senescence marker) expression. In conclusion, we showed that $10 \mathrm{ng} /$ $\mathrm{ml}$ of FGF-2 was inadequate for ex vivo expansion of BMSCs because $10 \mathrm{ng} / \mathrm{ml}$ of FGF-2 induced growth retardation via ERK1/2 de-phosphorylation and induction of autophagy and senescence in BMSCs.
\end{abstract}

Key Words: Mesenchymal stem cell, Fibroblast growth factor-2, Senescence, Autophagy, Proliferation

\section{INTRODUCTION}

Mesenchymal stem cells (MSCs) have been used for cell-based tissue engineering and regenerative medicine due to their capacity of self-renewal, multi-lineage differentiation (Pittenger et al., 1999; Jiang et al., 2002; Schwartz et al., 2002), and their therapeutic properties, such as migration to the site of damage (Caplan, 1991; Prockop, 1997), expression of trophic factors, and immunosuppressive potential (Kwon et al., 2006; Prockop and Olson, 2007). Although MSCs can be expanded for clinical use in a relatively short time period (Colter et al., 2000; Sekiya et al., 2002), it has been reported that the proliferation rate and differentiation ability of MSCs are gradually decreased and MSCs become easily senescent during serial passages (Digirolamo et al., 1999; Ksiazek, 2009). Thus, to obtain large number of MSCs, many investigators have extensively examined optimal culture parameters, including basal medium, glucose concentration, stable glutamine, mononuclear cell plating density, MSC passaging density, plastic surface quality, and growth factors (Colter et al., 2000; Lee et al., 2013; Sekiya et al.,

*Received: March 21, 2017 / Revised: May 17, 2017 / Accepted: June 5, 2017

${ }^{\dagger}$ Corresponding author: Young Woo Eom. Cell Therapy and Tissue Engineering Center, Wonju College of Medicine, Yonsei University, 20 Ilsan-ro, Wonju, Gangwon-do 26426, Korea.

Tel: +82-33-741-0260, Fax: +82-33-743-0411, e-mail: yweom@yonsei.ac.kr

(C) The Korean Society for Biomedical Laboratory Sciences. All rights reserved.

(C) This is an Open Access article distributed under the terms of the Creative Commons Attribution Non-Commercial License (http://creativecommons.org/licenses/by-nc/3.0/) which permits unrestricted non-commercial use, distribution, and reproduction in any medium, provided the original work is properly cited. 
2002; Yang et al., 2015). Moreover, it is important to establish in vitro culture conditions that maintain the stemness, which can be defined by their potential to proliferate and differentiate and known to decrease during serial passage gradually. To increase the growth rates of MSCs, fibroblast growth factor (FGF)-2, platelet-derived growth factor (PDGF), epidermal growth factor (EGF), and vascular endothelial growth factor (VEGF) are often used to obtain large number of MSCs in ex vivo expansion (Zaragosi et al., 2006; Larghero et al., 2008; Tarte et al., 2010). Among these factors, FGF-2 is the most common growth supplement used in MSC culture media.

FGFs belong to a family of heparin-binding growth factors that are known to regulate proliferation, migration, survival, and differentiation in many different cell types and tissues (Oh and Eom, 2016; Okada-Ban et al., 2000; Eswarakumar et al., 2005). FGFs have a heparin-binding site and interaction with heparin-like molecules is necessary for their stable interaction with FGFRs and local signaling (Goetz et al., 2007). In humans, 22 members of the FGFs family have been identified. FGFs are secreted during the healing process of fractures or in sites of bone surgery, implying that FGFs are an important factor in bone development and regeneration (Bolander, 1992). In stem cells such as hematopoietic, mesenchymal, neural, and embryonic stem cells, FGFs regulate the self-renewal, maintenance, and proliferation (Craig et al., 1996; Quito et al., 1996; Gritti et al., 1999; Yeoh and de Haan, 2007). FGFs bind tyrosine-kinase receptors, FGF receptors (FGFR) 1-4 and then activate mainly two signaling cascades downstream of the FGFRs to stimulate proliferation or survival. One is the Ras- Raf- mitogenactivated protein kinase (MAPK) proliferation pathway (Kouhara et al., 1997). In parallel, the other is phosphatidylinositol-3-kinase (PI3K)-Akt cell survival pathway (Kouhara et al., 1997; Schlessinger, 2004).

Previously, we reported that FGF-2 stimulated proliferation via $\mathrm{AKT}$ and ERK activation and suppressed autophagy and senescence in long-term culture of BMSCs (Eom et al., 2014). Although FGF-2 increased proliferation potential in a dose dependent manner during short term cultures approximately 3 days or early passage, growth rate decreased rapidly by high dose of FGF-2 treatment during long-term culture.
In this study, we showed that high dose of FGF-2 (>5 ng/ $\mathrm{ml}$ ) decreased growth rate at late passage by suppression of ERK signaling.

\section{MATERIALS AND METHODS}

\section{Cell culture}

The Institutional Review Board of Yonsei University Wonju College of Medicine approved this study. Human bone marrows $(\mathrm{BM})$ of three healthy donors (age 21 40 years) were obtained with informed consent from Pharmicell Co., Ltd. (Sungnam, Korea). BMSCs were isolated and cultured as previously described (Jang et al., 2014; Bae et al., 2015). Briefly, mononuclear cells from BM aspirates were isolated by density-gradient centrifugation (Histopaque1077, Sigma-Aldrich, St. Louis, MO, USA). Mononuclear cells $\left(2 \sim 3 \times 10^{5}\right.$ cells $\left./ \mathrm{cm}^{2}\right)$ were plated in a $75 \mathrm{~cm}^{2}$ flask (Falcon, Franklin Lakes, NJ, USA) with low-glucose Dulbecco's modified Eagle's medium (LG-DMEM; GibcoBRL, Grand Island, NY, USA) containing 10\% fetal bovine serum (FBS, GibcoBRL) and penicillin/streptomycin (GibcoBRL), and cultured at $37^{\circ} \mathrm{C}$ in a $5 \% \mathrm{CO}_{2}$ atmosphere. After 5 days, the medium was changed to remove non-adherent cells. The medium was changed twice weekly and cells were passaged when cells reached $90 \%$ confluence (passage 0). Expanded cells were cryopreserved at passage 1 . To perform experiments, cryopreserved cells were thawed, expanded to one more passage, and then these cells were used for this study. Population doubling time (PDT) was determined by dividing the total number of hours in culture by the number of doublings. To evaluate the effects of FGF-2 (R\&D) on proliferation potential, autophagy, and senescence, BMSCs were cultured with 1 or $10 \mathrm{ng} / \mathrm{ml}$ of FGF-2 during serial passage for two months.

\section{Immunoblotting}

The BMSCs were cultured with FGF-2 during the indicated time points or each passage. Cells were lysed in sodium dodecyl sulfate/polyacrylamide gel electrophoresis (SDS-PAGE) sample buffer (62.5 mM Tris (pH 6.8), 1\% SDS, $10 \%$ glycerol, and $5 \% \beta$-mercaptoethanol), boiled for 5 min, subjected to SDS-PAGE, and transferred to an Immo- 
bilon membrane (Millipore, Bedford, MA, USA). The membrane was blocked with 5\% skim milk for $30 \mathrm{~min}$ in TBST [Tris-buffered saline (20 mM Tris, $150 \mathrm{mM} \mathrm{NaCl} \mathrm{pH} \mathrm{7.6)}$ containing $0.05 \%$ Tween 20 ] and then probed with primary antibodies against AKT, phospho-AKT, ERK, and phosphoERK (each diluted 1:1,000, purchased from Cell Signaling Technology, Beverly, MA, USA), LC3 (1:1,000, purchased from Medical \& Biological Laboratorie, Nagoya, Japan), $\alpha$-tubulin (1:2,000, purchased from Santa Cruz Biotechnology, Santa Cruz, CA, USA) for overnight at $4{ }^{\circ} \mathrm{C}$. After 3 washes with TBST, the membrane was incubated with HRP-conjugated anti-mouse or anti-rabbit antibodies (1: 2,000, purchased from Santa Cruz Biotechnology, Santa Cruz) according to the host of the primary antibody for 1 hour at room temperature. The membrane was finally washed 3 times with TBST, immunoreactivity of bound primary antibodies was visualized with an EZ-Western Lumi Pico
(DOGEN, Seoul, Korea) and photographed under a FluorChem FC2 system (Alpha Innotech, Santa Clara, CA, USA).

\section{Senescence-associated $\beta$-Galactosidase ( $\beta$-gal) staining}

BMSCs were stained for $\beta$-gal activity as described by Dimri et al. (Dimri et al., 1995). Briefly, after 2 month culture of BMSCs with or without FGF-2 (1 or $10 \mathrm{ng} / \mathrm{ml})$, $4 \times 10^{4}$ cells were seeded in 12 -well plate. $\beta$-gal activity was assessed with a senescence $\beta$-gal staining kit (Cell Signaling Technology) according to the manufacturer's instructions. The percentage of senescent cells was represented by the number of stained cells in the total population.

\section{RESULTS}

\section{Proliferation of BMSCs by FGF-2}

Previously, we reported that $1 \mathrm{ng} / \mathrm{ml}$ of FGF-2 can increase
A

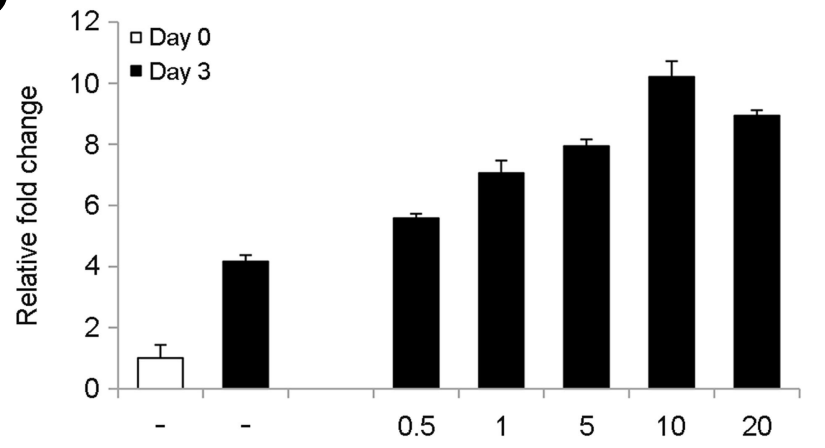

B

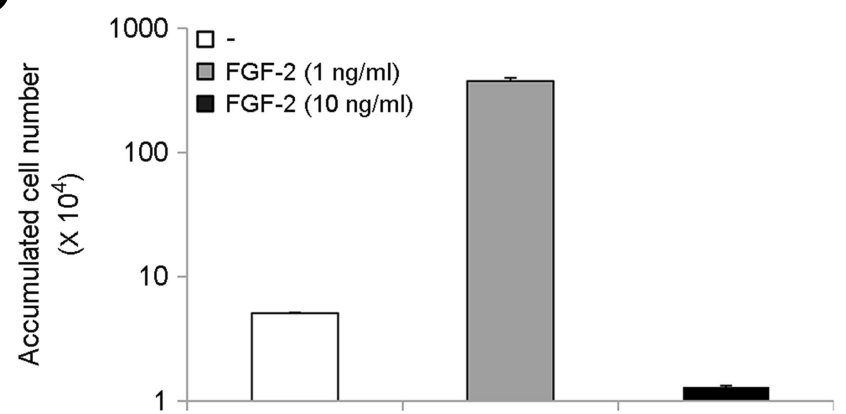

○

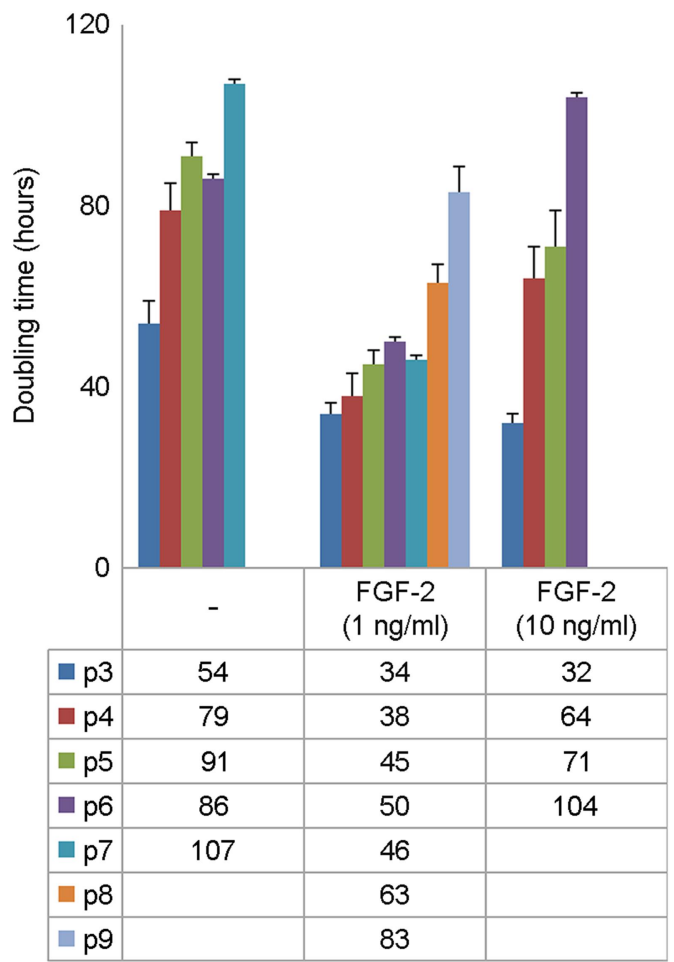

Fig. 1. Proliferation potential of BMSCs treated with FGF-2. A) Relative increase of growth by treatment with FGF-2 (0 20 ng/ml) for 3 days. B) Accumulated cell number by treatment with 1 or $10 \mathrm{ng} / \mathrm{ml}$ of FGF-2 during serial passage for 2 months. C) Population doubling times of BMSCs during serial passage for 2 months. Results are expressed as mean \pm SD. 
the proliferation of BMSCs, but we observed a significant decrease in proliferation rate when $10 \mathrm{ng} / \mathrm{ml}$ of FGF-2 was used for culturing BMSCs for longs periods (Eom et al., 2014). In order to determine the optimal concentration of FGF-2 for BMSC culture, cells were treated with different concentrations of FGF-2 for 3 days. FGF-2 increased the proliferation of BMSCs in a dose dependent manner up to $10 \mathrm{ng} / \mathrm{ml}$ concentration, but decreased the proliferation rate at $20 \mathrm{ng} / \mathrm{ml}$ concentration (Fig. 1A). To determine the changes in population doubling time (PDT) and the total accumulated number of cells that could be obtained by 2 months culture, $1 \mathrm{ng} / \mathrm{ml}$ or $10 \mathrm{ng} / \mathrm{ml}$ of FGF-2 were treated for 2 months in a BMSC culture. Unexpectedly, the prolif-

A

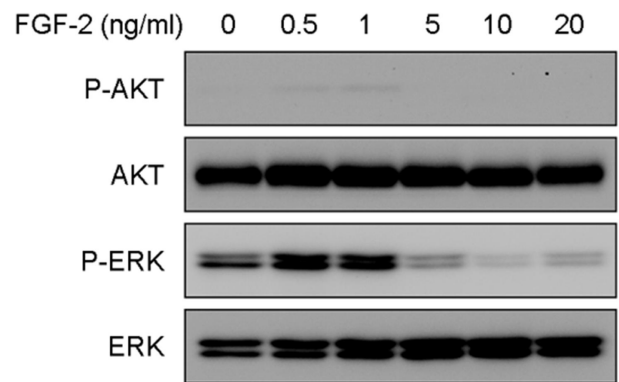

eration rate, subculture number, and accumulated cell number of BMSCs was significantly decreased in $10 \mathrm{ng} / \mathrm{ml}$ of FGF-2-treated culture (Fig. 1B). Moreover, PDT increased from 32 hours in the first subculture to 104 hours in the fourth subculture (Fig. 1C). On the other hand, $1 \mathrm{ng} / \mathrm{ml}$ of FGF-2 showed increased proliferation (Fig. 1A), relatively short PDT (Fig. 1B), and approximately 100 times more cells than the control group (Fig. 1C). These results suggest that the use of high concentrations of FGF-2 for BMSC culture is inappropriate.

\section{Proliferation signals activated by FGF-2 in BMSCs}

Previously, we observed that $1 \mathrm{ng} / \mathrm{ml}$ of FGF-2 promoted
B

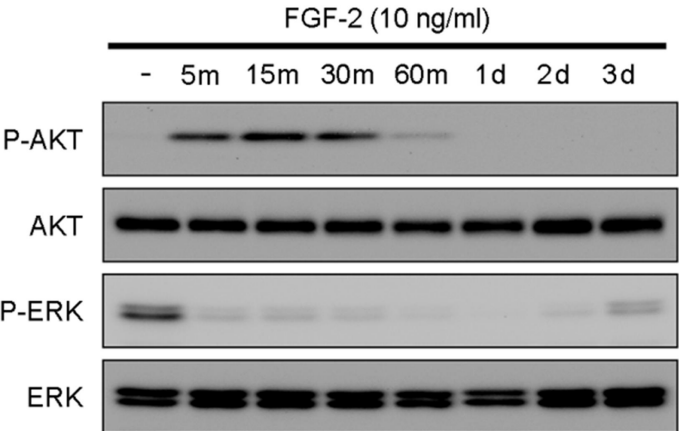

C

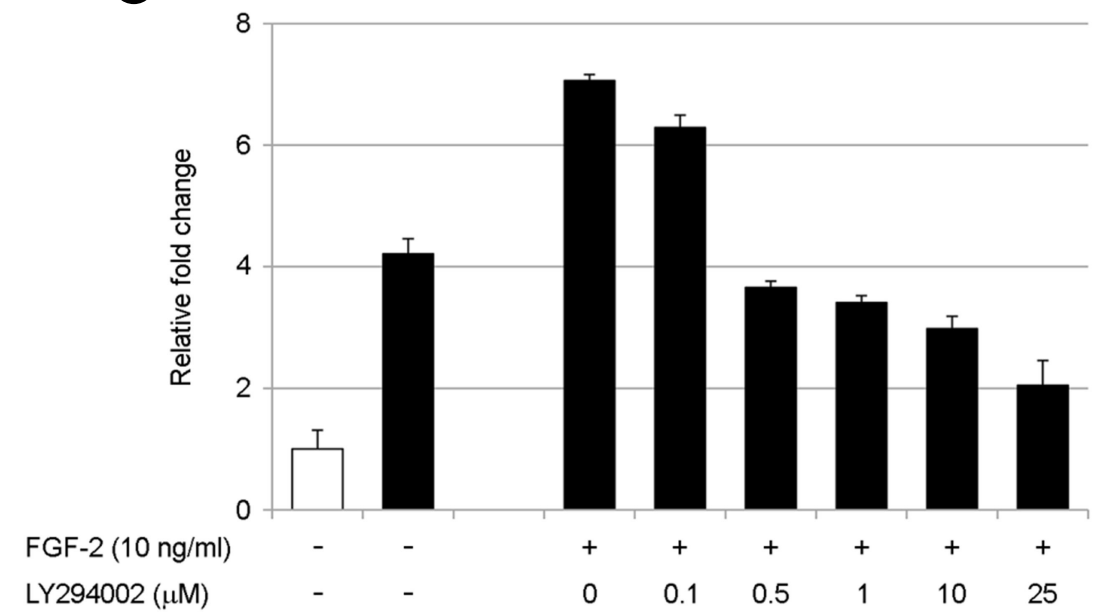

Fig. 2. Proliferation signals activated by FGF-2 in BMSCs. BMSCs were treated with FGF- 2 in a dose (at $0 \sim 20 \mathrm{ng} / \mathrm{ml}$ for 3 days) and time (for $0 \sim 3$ days at $10 \mathrm{ng} / \mathrm{ml}$ ) dependent manners. A) Activation of AKT and ERK by FGF-2 at different concentrations $(0.5 \sim 20 \mathrm{ng} / \mathrm{ml})$ for 3 days. B) Activation of AKT and ERK for different time points by $10 \mathrm{ng} / \mathrm{ml}$ of FGF-2. C) Inhibitory effects of LY294002 on growth of BMSCs. $10 \mathrm{ng} / \mathrm{ml}$ of FGF-2-dependent growth increase was reversed by inhibitors of AKT in a dose-dependent manner. Results are expressed as mean $\pm \mathrm{SD}$. 
proliferation of BMSCs by activating AKT and ERK (Eom et al., 2014). BMSCs were treated with FGF-2 at different concentrations $(0.5 \sim 20 \mathrm{ng} / \mathrm{ml})$ for 3 days to confirm the phosphorylation of AKT and ERK. ERK were phosphorylated only at a low concentration of $0.5 \sim 1 \mathrm{ng} / \mathrm{ml}$, but it was observed that the phosphorylation of ERK was less than that of the control group at concentrations greater than $1 \mathrm{ng} / \mathrm{ml}$ (Fig. 2A). In order to analyze the change of phosphorylation of AKT and ERK up to 3 days after FGF-2 treatment, $10 \mathrm{ng} / \mathrm{ml}$ of FGF-2 was treated. Phosphorylation of AKT was observed for 5 to $30 \mathrm{~min}$, but phosphorylation of ERK was not observed at all and was not even phosphorylated than in the control group (Fig. 2B). When LY294002, an inhibitor of PI3K, which can inhibit AKT activity, was treated with $10 \mathrm{ng} / \mathrm{ml}$ of FGF-2, the proliferation of BMSCs decreased in a dose dependent manner (Fig. 2C). These results suggest that $10 \mathrm{ng} / \mathrm{ml}$ of FGF-2 may induce BMSC proliferation through the activation of AKT but it does not

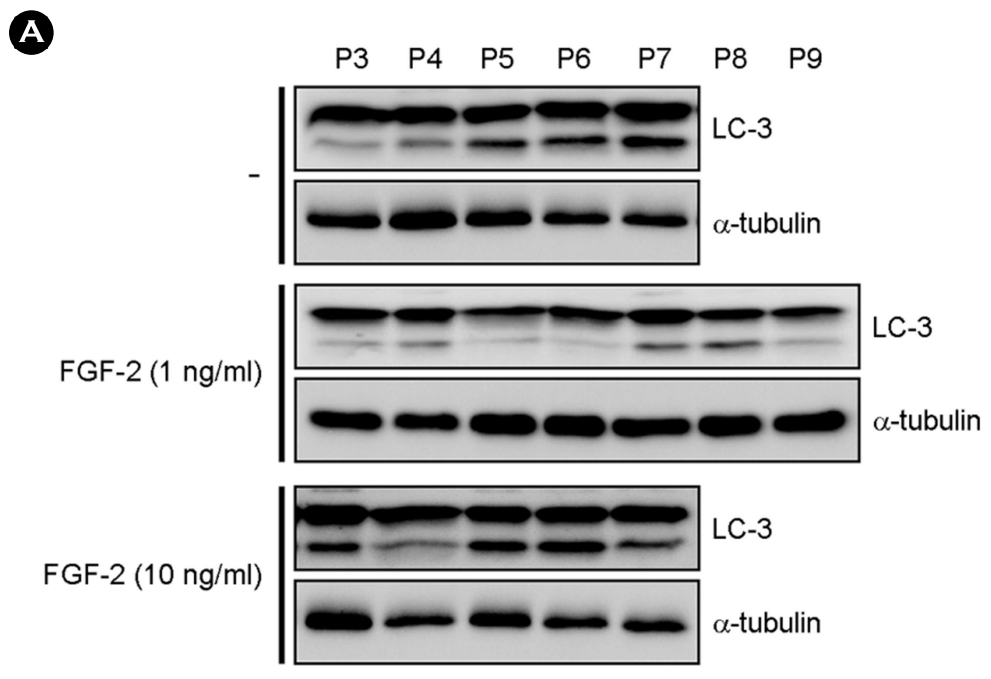

B

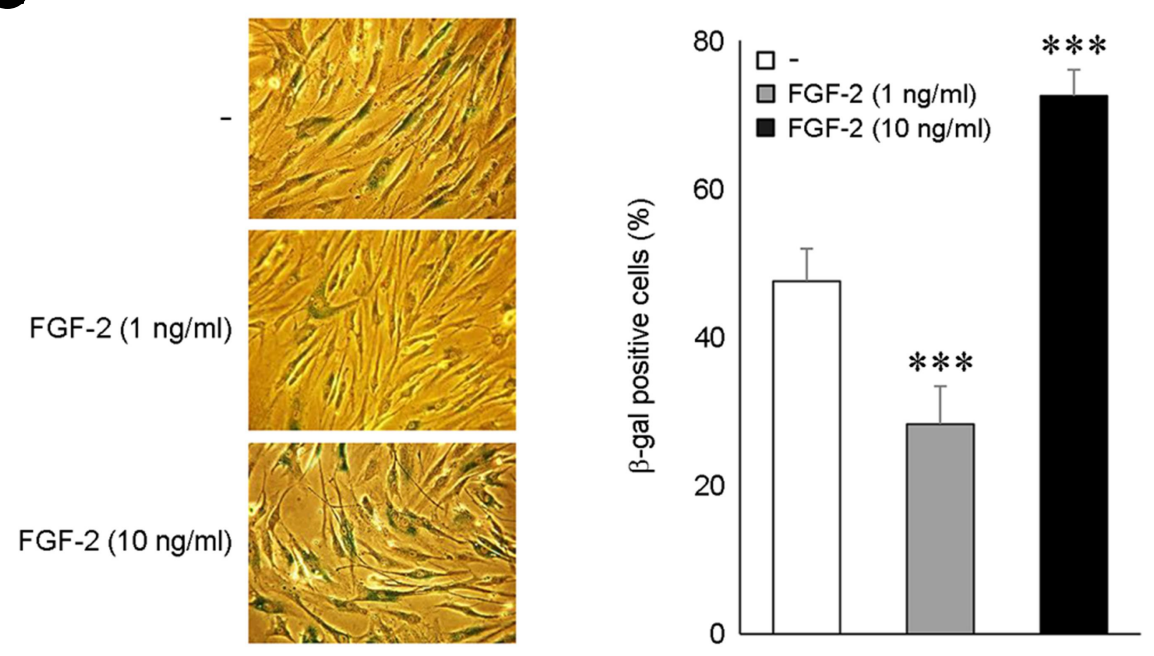

Fig. 3. Effect of FGF-2 on autophagy and senescence in BMSCs. A). Expression of LC3-II during serial passage with or without 1 or $10 \mathrm{ng} /$ $\mathrm{ml}$ of FGF-2. B) Effect of growth factors on SA- $\beta$-gal activity. SA- $\beta$-gal-positive cells were photographed (100X) with a phase contrast microscope and enumerated. At least 200 cells were counted from six different fields and the percentages of positive cells were determined. Results are expressed as mean $\pm \mathrm{SD}(\mathrm{n}=6 \sim 7) ; * * *<0.001$ versus control. 
require the activity of ERK.

\section{Autophagy and senescence of BMSCs by FGF-2}

Previously, we reported that $1 \mathrm{ng} / \mathrm{ml}$ of FGF-2 promoted the proliferation of BMSCs and alleviated autophagy and cellular senescence (Eom et al., 2014). In order to investigate changes in autophagy and cellular senescence by $10 \mathrm{ng} / \mathrm{ml}$ of FGF-2, $10 \mathrm{ng} / \mathrm{ml}$ of FGF-2 was continuously treated with BMSC culture. The expression of LC3-II used as a marker of autophagy was gradually increased in the control group, but no significant change in expression was observed at 1 $\mathrm{ng} / \mathrm{ml}$ of FGF-2. On the other hand, in BMSCs treated with $10 \mathrm{ng} / \mathrm{ml}$ of FGF-2, LC3-II expression was slightly increased compared to the control group (Fig. 3A). In cellular senescence, $1 \mathrm{ng} / \mathrm{ml}$ of FGF-2 reduced cellular senescence, but $10 \mathrm{ng} / \mathrm{ml}$ of FGF-2 promoted senescence more so than the control group (Fig. 3B). These results suggest that 10 $\mathrm{ng} / \mathrm{ml}$ of FGF-2 may inhibit BMSC proliferation by inducing autophagy and senescence of BMSCs.

\section{DISCUSSION}

FGF-2 was able to stimulate proliferation of BMSCs in a dose dependent manner, but continuous prolonged highdose treatment significantly slowed proliferation rate. FGF-2 at $10 \mathrm{ng} / \mathrm{ml}$ activated AKT, but ERK promoted dephosphorylation. In addition, $10 \mathrm{ng} / \mathrm{ml}$ FGF-2 increased autophagy and increased cellular senescence. In order to use MSCs in clinical studies for the treatment of intractable diseases, a large number of cells are required. Although MSCs have been reported to be able to proliferate to a sufficient number of cells for a relatively short period of time (Colter et al., 2000; Sekiya et al., 2002), MSCs have been reported to slowly decrease their proliferative capacity during prolonged cultures (Eom et al., 2014). FGF-2, FGF-4, and stromalderived factor (SDF) -1 is known to modulate the proliferative capacity of MSCs (Quito et al., 1996; Solchaga et al., 2005). Indeed, these growth factors have been used for the cultivation of many primary cells, including mesenchymal stem cells. However, as the results of this study indicate, it should be considered that the use of a growth factor concentration above a certain level in the culture of MSCs may deteriorate the proliferative capacity.

Since several growth factors (FGF-2, EGF, TGF-beta, and HGF) have been reported to regulate the differentiation potential of MSCs (Sanchez and Fabregat, 2010). In fact, long-term treatment with $1 \mathrm{ng} / \mathrm{ml}$ of FGF-2 resulted in a decrease of the differentiation potentials (Eom et al., 2014) and the expression of CD73 and CD90, the cell surface antigens of MSCs, and a marked increase in the expression of HLA-DR (data not shown). Therefore, when growth factors are used to increase the proliferative capacity of MSCs, the types and concentrations of growth factors that influence on differentiation potentials and expression of cell surface antigens in MSCs must be evaluated. In addition, autophagy and cellular senescence gradually increase during culture (Eom et al., 2014). Therefore, when growth factors are used to increase the proliferative capacity, the effect of growth factors on autophagy and senescence of MSCs must be analyzed as well. In conclusion, although we can secure the number of MSCs within a short period of time using growth factors, because growth factors can regulate differentiation, autophagy, aging, and cell surface antigen expression in MSCs, the type and amount of growth factor used in the culture should be strictly determined.

\section{ACKNOWLEDGEMENTS}

The present study was supported by Basic Science Research Program through the National Research Foundation of Korea (NRF) funded by the Ministry of Education (NRF2015R1D1A1A02062064).

\section{CONFLICT OF INTEREST}

The authors have no conflicts of interest to disclose.

\section{REFERENCES}

Bae SH, Ryu H, Rhee KJ, Oh JE, Baik SK, Shim KY, Kong JH, Hyun SY, Pack HS, Im C, Shin HC, Kim YM, Kim HS, Eom YW, Lee JI. L-ascorbic acid 2-phosphate and fibroblast growth factor-2 treatment maintains differentiation potential in bone marrow-derived mesenchymal stem cells through expression of hepatocyte growth factor. Growth Factors. 2015. 33: 71-78. Bolander ME. Regulation of fracture repair by growth factors. 
Proceedings of the Society for Experimental Biology and Medicine. 1992. 200: 165-170.

Caplan AI. Mesenchymal stem cells. Journal of Orthopaedic Research. 1991. 9: 641-650.

Colter DC, Class R, DiGirolamo CM, Prockop DJ. Rapid expansion of recycling stem cells in cultures of plastic-adherent cells from human bone marrow. Proceedings of the National Academy of Sciences of the United States of America. 2000. 97: 3213 -3218 .

Craig CG, Tropepe V, Morshead CM, Reynolds BA, Weiss S, van der Kooy D. In vivo growth factor expansion of endogenous subependymal neural precursor cell populations in the adult mouse brain. The Journal of Neuroscience. 1996. 16: 2649 -2658 .

Digirolamo CM, Stokes D, Colter D, Phinney DG, Class R, Prockop DJ. Propagation and senescence of human marrow stromal cells in culture: a simple colony-forming assay identifies samples with the greatest potential to propagate and differentiate. British Journal of Haematology. 1999. 107: 275-281.

Dimri GP, Lee X, Basile G, Acosta M, Scott G, Roskelley C, Medrano EE, Linskens M, Rubelj I, Pereira-Smith O, Peacocke M, Campisi J. A biomarker that identifies senescent human cells in culture and in aging skin in vivo. Proceedings of the National Academy of Sciences of the United States of America. 1995. 92: 9363-9367.

Eom YW, Oh JE, Lee JI, Baik SK, Rhee KJ, Shin HC, Kim YM, Ahn CM, Kong JH, Kim HS, Shim KY. The role of growth factors in maintenance of stemness in bone marrow-derived mesenchymal stem cells. Biochemical and Biophysical Research Communications. 2014. 445: 16-22.

Eswarakumar VP, Lax I, Schlessinger J. Cellular signaling by fibroblast growth factor receptors. Cytokine \& Growth Factor Reviews. 2005. 16: 139-149.

Goetz R, Beenken A, Ibrahimi OA, Kalinina J, Olsen SK, Eliseenkova AV, Xu C, Neubert TA, Zhang F, Linhardt RJ, Yu X, White KE, Inagaki T, Kliewer SA, Yamamoto M, Kurosu H, Ogawa Y, Kuro-o M, Lanske B, Razzaque MS, Mohammadi M. Molecular insights into the klotho-dependent, endocrine mode of action of fibroblast growth factor 19 subfamily members. Molecular and Cellular Biology. 2007. 27: 3417-3428.

Gritti A, Frolichsthal-Schoeller P, Galli R, Parati EA, Cova L, Pagano SF, Bjornson CR, Vescovi AL. Epidermal and fibroblast growth factors behave as mitogenic regulators for a single multipotent stem cell-like population from the subventricular region of the adult mouse forebrain. The Journal of
Neuroscience. 1999. 19: 3287-3297.

Jang YO, Kim YJ, Baik SK, Kim MY, Eom YW, Cho MY, Park HJ, Park SY, Kim BR, Kim JW, Soo Kim H, Kwon SO, Choi EH, Kim YM. Histological improvement following administration of autologous bone marrow-derived mesenchymal stem cells for alcoholic cirrhosis: a pilot study. Liver International 2014. 34: 33-41.

Jiang Y, Jahagirdar BN, Reinhardt RL, Schwartz RE, Keene CD, Ortiz-Gonzalez XR, Reyes M, Lenvik T, Lund T, Blackstad M, Du J, Aldrich S, Lisberg A, Low WC, Largaespada DA, Verfaillie CM. Pluripotency of mesenchymal stem cells derived from adult marrow. Nature. 2002. 418: 41-49.

Kouhara H, Hadari YR, Spivak-Kroizman T, Schilling J, Bar-Sagi D, Lax I, Schlessinger J. A lipid-anchored Grb2-binding protein that links FGF-receptor activation to the Ras/MAPK signaling pathway. Cell. 1997. 89: 693-702.

Ksiazek K. A comprehensive review on mesenchymal stem cell growth and senescence. Rejuvenation Research. 2009. 12: 105-116.

Kwon GC, Kwon HM, Son GS. A study of peripheral blood stem cell collection and bone marrow engraftment after periphera blood stem cell transplantation. Korean Journal of Clinical Laboratory Science. 2006. 38: 9-15.

Larghero J, Farge D, Braccini A, Lecourt S, Scherberich A, Fois E, Verrecchia F, Daikeler T, Gluckman E, Tyndall A, BocelliTyndall C. Phenotypical and functional characteristics of in vitro expanded bone marrow mesenchymal stem cells from patients with systemic sclerosis. Annals of the Rheumatic Diseases. 2008. 67: 443-449.

Lee JH, Rhee KJ, Jung DJ. Construction of 3D culture medium with elastin-like polypeptide (ELP) hydrogel for human pluripotent stem cells. Journal of Experimental \& Biomedical Sciences. 2013. 19: 41-47.

Oh JE, Eom YW. Maintenance of proliferation and adipogenic differentiation by fibroblast growth factor- 2 and dexamethasone through expression of hepatocyte growth factor in bone marrow-derived mesenchymal stem cells. Biomedical Science Letters. 2016. 22: 1-8.

Okada-Ban M, Thiery JP, Jouanneau J. Fibroblast growth factor-2. The International Journal of Biochemistry \& Cell Biology. 2000. 32: 263-267.

Pittenger MF, Mackay AM, Beck SC, Jaiswal RK, Douglas R, Mosca JD, Moorman MA, Simonetti DW, Craig S, Marshak DR. Multilineage potential of adult human mesenchymal stem cells. Science. 1999. 284: 143-147. 
Prockop DJ. Marrow stromal cells as stem cells for nonhematopoietic tissues. Science. 1997. 276: 71-74.

Prockop DJ, Olson SD. Clinical trials with adult stem/progenitor cells for tissue repair: let's not overlook some essential precautions. Blood. 2007. 109: 3147-3151.

Quito FL, Beh J, Bashayan O, Basilico C, Basch RS. Effects of fibroblast growth factor-4 (k-FGF) on long-term cultures of human bone marrow cells. Blood. 1996. 87: 1282-1291.

Sanchez A, Fabregat I. Growth factor- and cytokine-driven pathways governing liver stemness and differentiation. World Journal of Gastroenterology. 2010. 16: 5148-5161.

Schlessinger J. Common and distinct elements in cellular signaling via EGF and FGF receptors. Science. 2004. 306: 1506-1507.

Schwartz RE, Reyes M, Koodie L, Jiang Y, Blackstad M, Lund T, Lenvik T, Johnson S, Hu WS, Verfaillie CM. Multipotent adult progenitor cells from bone marrow differentiate into functional hepatocyte-like cells. The Journal of Clinical Investigation. 2002. 109: 1291-1302.

Sekiya I, Larson BL, Smith JR, Pochampally R, Cui JG, Prockop DJ. Expansion of human adult stem cells from bone marrow stroma: conditions that maximize the yields of early progenitors and evaluate their quality. Stem Cells. 2002. 20: 530-541.

Solchaga LA, Penick K, Porter JD, Goldberg VM, Caplan AI, Welter

JF. FGF-2 enhances the mitotic and chondrogenic potentials of human adult bone marrow-derived mesenchymal stem cells. Journal of Cellular Physiology. 2005. 203: 398-409.
Tarte K, Gaillard J, Lataillade JJ, Fouillard L, Becker M, Mossafa H, Tchirkov A, Rouard H, Henry C, Splingard M, Dulong J, Monnier D, Gourmelon P, Gorin NC, Sensebe L, Societe Francaise de Greffe de Moelle et Therapie C. Clinical-grade production of human mesenchymal stromal cells: occurrence of aneuploidy without transformation. Blood. 2010. 115: 1549 $-1553$.

Yang JY, Kwon JH, Kim MY, Bae YK, Jin HJ, Park HY, Eom YW, Rhee KJ. In vitro expansion of umbilical cord blood derived mesenchymal stem cells (UCB-MSCs) under hypoxic conditions. Biomedical Science Letters. 2015. 21: 40-49.

Yeoh JS, de Haan G. Fibroblast growth factors as regulators of stem cell self-renewal and aging. Mechanisms of Aging and Development. 2007. 128: 17-24.

Zaragosi LE, Ailhaud G, Dani C. Autocrine fibroblast growth factor 2 signaling is critical for self-renewal of human multipotent adipose-derived stem cells. Stem Cells. 2006. 24: 2412-2419.

http://dx.doi.org/10.15616/BSL.2017.23.2.49

Cite this article as: Shim KY, Tuj Saima Fatema, Eom YW. High Dose of FGF-2 Induced Growth Retardation via ERK1/2 De-phosphorylation in Bone Marrow-derived Mesenchymal Stem Cells. Biomedical Science Letters. 2017. 23: 49-56. 